Irina N. Ščukina

\title{
Ruska televizija leta 2010 skozi prizmo nacionalne mentalitete
}

Ključne besede: množični mediji, nacionalna mentaliteta, pravoslavne pridige, patriarh Kiril, občinstvo

\section{Uvod}

Ni skrivnost, da pošiljatelj najuspešneje vpliva na prejemnika tedaj, ko se, "upoštevajoč posebnosti poslušalcev/gledalcev«, pri uporabi sredstev (zavestno ali nezavedno) opira na informacijo o družbeno sprejetem vrednostnem sistemu, ki ga podpira prejemnikova nacionalno opredeljena mentaliteta.

Osnovni cilj sloga v proizvodih za množično komunikacijo, ko ti informirajo najširše sloje prebivalstva o sodobnih dogodkih, je vplivati na družbeno zavest. (Solganik in Dronyaeva, 2002, 160)

Z vplivom na družbeno zavest množični mediji sodelujejo pri ustvarjanju individualne, socialne in končno tudi nacionalno opredeljene podobe sveta. »Množični mediji so najvplivnejša sfera sodobne kulture. Prav v množičnih medijih se formira nova paradigma vrednot, tu se dogaja prekodiranje hierarhično-vrednostne strukture nacionalne mentalitete.« (Annenkova, 2010a, 40)

Množični mediji opravljajo kompleksno nalogo, ki je takšna zaradi poslušalstva. To je neobvladljivo nehomogeno, ne glede na materialni status njegovih posameznikov. N. S. Trubeckoj v članku Verhi i nizy rsskoj kul'tury (Etničeskaya osnova russkoj kul'tury) znotraj sicer enotne družbe utemeljuje neizogibno dvodelnost nacionalne kulture $\mathrm{z}$ naslednjim argumentom:

Vsaka diferencirana kultura vključuje dve nepogrešljivi plasti, ki ju lahko nazorno označimo za zgornjo in spodnjo plast nacionalnokulturne zgradbe. Kot spodnjo plast razumemo tisto zalogo kulturnih vrednot, ki zadovoljuje potrebe najširših slojev nacionalne celote, tako imenovane ljudske množice. Ker se te vrednote ustvarjajo znotraj ljudskih množic, so relativno elementarne in jih individualna kreativnost odločilneje ne zaznamuje. Ko posamezne kulturne vrednote preidejo iz zgornje $\mathrm{v}$ spodnjo plast, do neke mere že samo zaradi tega prehoda neizbežno izgubijo pečat individualnosti 
in se poenostavijo, prilagajajo se splošnemu kontekstu vrednot, ki izhajajo izključno iz spodnje plasti. (Trubeckoj, 2007, 178)

Verifikacija tega sklepa ne potrebuje posebne analize: kateri koli član družbe občuti prisotnost teh dveh komponent nacionalne kulture. A za razliko od »spodnje plasti« vrednote »zgornje plasti /.../ ustrezajo bolj rafiniranim potrebam, zahtevnejšim okusom. Zato so te vselej sorazmerno kompleksnejše in manj elementarne od vrednot spodnje plasti« (Trubeckoj, 2007, 179). Vidimo torej, da prekodiranje vrednostnih struktur, ki ga je prepoznala A. N. Annenkova, predstavlja usmeritev k različnima prejemnikoma. Včasih se zdi, da zgornja in spodnja plast ruske kulture izdelujeta absolutno nasprotni si podobi sveta. Ali pa ju zato lahko postavimo v opozicijsko razmerje?

\section{Struktura mentalitete}

Mentaliteta je mnoštvo predstav o svetu, ki ima prepoznavno strukturo, drugačno od hierarhične vrednostne strukture. Seveda je možno, da razliko vzpostavlja zgolj terminologija, vendar temelja te strukture ne predstavljajo »spodnji, ostali« (kar kot prioriteto reklamnih oglasov beležijo raziskave E. Dichterja), marveč gre tu za enostavne osnovne predstave o svetu, ki si jih delijo vsi nosilci kake mentalitete, pri čemer ta podoba »odraža stanje sprejemanja realnosti, ki se je formiralo v preteklih obdobjih jezikovnega in družbenega razvoja. Na podlagi jezika ni mogoče enostransko presojati aktualnih predstav, ki jih ima kaka etnija o svetu, ni mogoče presojati njene aktualne konceptualne sfere (Prohorov in Sternin, 2007, 95-96). Bistvo mentalitete kake družbene ali poklicne skupnosti ali posameznika je določljivo na podlagi celote njihovih razmerij do sveta.

Mentaliteto posamezne osebe bo določal predvsem njen značaj. /.../ Mentaliteta se bo spreminjala skozi spreminjanje stanja zavesti. Človek, potopljen v namišljeno realnost, bo videl svet pač na svoj način. (Rudnev, 1997, 74)

$\mathrm{Z}$ vidika mentalitetne strukture se »spodnje plasti« (rus. nizy) vsake kulture formirajo na podlagi skupnih lastnosti človeškega in živalskega sveta, geografske poselitve in civilizacijskega stadija (Toynbee), pri čemer je slabše izobražen človek $\mathrm{z}$ minimalnim poznavanjem religije in okoliških religij, $\mathrm{z}$ minimalno izobrazbo in $\mathrm{s}$ podvrženostjo spolnim stereotipom toliko odvisnejši od tradicionalnega pogleda na svet, kakršnega je generirala njegova civilizacija, ki je nespremenljivo vzdrževala stoletne predstave o svetu in človeški skupnosti. »Gornje plasti« (rus. verhi) ruske kulture pa opredeljuje močna informiranost o civilizacijskih spremembah. Predstavniki teh plasti so dobro izobraženi, čeprav morda ateisti, so poznavalci religij, njihova bolj 
vsestranska podoba sveta pa prepoznava posamezne etape njenega formiranja in ustvarja nove osmislitve ter razširja in dopolnjuje splošnejšo mentaliteto.

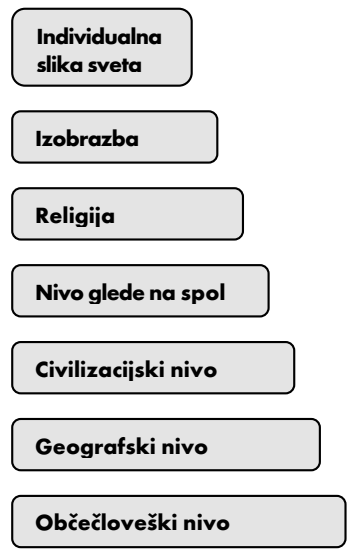

Slika 1: Struktura nacionalne mentalitete

Kot je razvidno iz mentalitete "gornje plasti«, v njej delujejo tudi vsi dejavniki, značilni za »spodnjo plast«, zaradi česar obeh plasti mentalitete ni mogoče postaviti $\mathrm{v}$ opozicijsko razmerje in zaradi česar so se avtorji ruskih televizijskih projektov v zadnjem desetletju uspešno obračali zgolj k osnovnim gradnikom nacionalne kulture. Enako so ravnali tudi gledališki kolektivi, posledično pa so tako gledališča kot televizijski programi izgubili pomemben del občinstva, ki se je pri iskanju odgovorov na zgodovinska vprašanja tradicionalno zatekal $\mathrm{k}$ institucijam, "v katerih se lahko pove veliko dobrega $($ N. V. Gogolj).

Leto 2010 je prineslo dolgo pričakovano spremembo v ponudbi televizijskih kanalov. Količina izobraževalnih programov je za nekajkrat narasla. Nenadoma je ruska televizija odkrila obsežen sloj gledalcev z interesi, ki so se razlikovali od predvidenih, predvsem pa možnost, da jim ponudi vzbujanje konstantnega interesa, tj. refleksijo, analizo in nove perspektive. Vodje televizijskih kanalov so povečali količino projektov za refleksivni interes občinstva, s tem pa delno zadostili tudi svoji osnovni funkciji, tj. formiranju družbene zavesti. ${ }^{1}$

K pomembnim novim projektom za preoblikovanje doslejšnje hierarhične vrednostne strukture lahko štejemo kanala "Ku'ltura« in "Akademija» ter oddajo »Sodba časa« na Petem kanalu, skoraj vsi kanali pa nadaljujejo teme oddaje »Okoli sveta«. Našteti projekti, zlasti pa televizijski prenosi oddaj Nikolaja Svanidze,

1 Takšna politika vzbuja upanje, da je status izobrazbe vse bolj pomemben. Tako bi s spiska zmerljivk izginile pejorativno konotirane besede, kot sta "pametnjakovič« in »inteligent «, ki jih z nerazumljivo naslado uporabljajo reklamni oglasi, npr. za pivo Klinskoje, ki nagovarja izključno mladino. 
skušajo premagati osrednjo težavo ruske zavesti, namreč odsotnost kulture izbire in pripravljenost slediti »vodji $«$.

\section{Televizijski projekti, orientirani na pravno zavest}

O ruski mentaliteti, vključno z vlogo jezika v njej, so precej pisali tako ruski kot tuji avtorji. Oglejmo si nekaj teh mentalitetnih prvin.

$\mathrm{V}$ začetku devetdesetih let, $\mathrm{v}$ času zloma državnih in oblastniških struktur, je bil sovjetski človek prepuščen neusmiljenim preizkušnjam. Ne z učenjem, marveč prek trpljenjske izkušnje je moral dojeti svobodo kot uzaveščeno nujnost in razumsko sprejeti idejo o svobodi, ki se neha tam, kjer se začne svoboda drugega. V izdelavi kompromisa med življenjem po zakonu in življenjem v pravici je moral dati prednost zakonu. Ta mučni proces še vedno ni zaključen. Kljub resnim potrebam po pravni izobrazbi in vzpostavitvi ustanov, ki bi jo mogle izpeljati, do tega ni prišlo, čeprav so rezultati analitične raziskave, ki je želela odgovoriti na vprašanje, kako se konceptualizira pojem »pravičnost«, razkrili, da se $\mathrm{z}$ vidika ruske zavesti pojem pravičnosti dojema izključno $\mathrm{z}$ ozirom na subjekt govora - to dokazujejo že pregovori (v dobesednem prevodu, op. prevajalca): »za nami je lahko potop - ni treba, da raste trava«, »ni važen prijatelj, marveč lasten trebuh«) - ali vsaj z ozirom na njemu najbližje druge (»resda dete ni zdravo, a očetu in materi ljubo«, »vsakdo vidi svoje, četudi nesnažno, kot čisto«). Če pravičnost postane problem znotraj kroga subjektovih najbližjih, se znova presoja s središčne pozicije subjekta (»kar tebe boli, prijatelja ne srbi«, »sestra ne rabi brata pri kuhi«). ${ }^{2}$

Rusi dojemajo "zakone in pravila tako, da ta $\mathrm{v}$ določenih situacijah za posameznika dopuščajo izjemo. Po trdnem prepričanju za vsa pravila velja, da je izjema možna (dopustna, če se nanaša name, a nedopustna, če se nanaša na druge). V ruski mentaliteti zakon ne velja za vse« (Prohorov in Sternin, 2007, 112). Šele v drugi polovici prvega desetletja 21. stoletja so se na televizijskih zaslonih pojavili programi s pravno vsebino: »Zvezni sodnik«, »Družinske zadeve«, »Ura sodbe«, »Stanovanjsko in komunalno gospodarstvo $(\check{Z} \mathrm{KH}) »$, »Sodba zapriseženih», »Sodne strasti« ipd. Gledalca naj bi na prvi pogled sicer zanimale samo peripetije prestopkov in pravosodne zanke v resničnostnem šovu, vendar se hkrati s tem v zavest (ali nezavedno) skrivoma prikrade spoznanje, da obstaja nekaj, kar vodi življenje ljudi na zaslonu. Vsak gledalec televizijskega programa bi težko prišel do spoznanja, da se je temu nečemu treba podrejati ${ }^{3}$ v svojem lastnem življenju, pomembno pa je, da tovrstne oddaje morda vsaj intuitivno vzbujajo zavest o Zakonu, ki ureja življenje državljanov.

2 Več o tem gl. v: Ščukina (2010).

3 A. Vežbickaya opisuje negativno naravnanost ruske mentalitete, fatalizem, v katerem glavni dejavnik, ki uravnava človekovo ravnanje, postane bog ali usoda: »človek obrača, Bog obrne«, »ne zareci se, da si ubežal malhi in ječi« ipd. 


\section{Kvalitetna televizija}

\section{Po mnenju I. V. Annenkove}

tipologija ruske časopisne produkcije v obdobju zadnjih petih ali desetih let $\mathrm{v}$ celoti sovpada s to, ki jo vzpostavljajo množični mediji po svetu, razcepila se je na t. i. »kvalitetne« in »množične« publikacije. Večina množičnih dnevnikov in revij (tiskanih množičnih medijev) je namenjena preživljanju prostega časa. Delež takih publikacij neustavljivo narašča; diferencirajo se glede na prejemnika (spol, interesna področja, hobiji, zanimanje za »junake«, tj. osebe v središču dogajanja), imajo pa visoko stopnjo posrednega in neposrednega vpliva na politiko domačih ( $\mathrm{tj}$. ruskih - op. prevajalca) množičnih medijev (Annenkova, 2009).

K temu dodajamo, da podobna tendenca zaznamuje tudi rusko televizijo. Odstotek »kvalitetnih« oddaj je bil pri tem na splošno nizek, na nekaterih kanalih celo ničeln (MTV, MuzTV, 2x2 idr.).

Leta 2010 pa se je količina »kvalitetnih « programov ruske televizije precej povečala. Večina od njih je vzgojno-izobraževalnega značaja, kar ni presenetljivo, saj rezultati dvajsetletnega obdobja, v katerem je ruska država podcenjevala izobrazbo - $\mathrm{k}$ čemur so precej prispevali tudi ruski množični mediji -, v zadrego spravljajo tudi najdrznejša prepričanja, po katerih »trg razvrednoti vse drugo« in s svojimi zakoni, ki naj edini vladajo družbi, nadomešča nravstvene zakone. Vrhu tega spodaj navedeni pregovori vzbujajo vtis, da rusko mentaliteto zaznamujeta nasprotovanje in ugovarjanje vsemu, kar zahteva bodisi oblast oziroma vlada bodisi razum ali situacija: »učenje - muka«, »brez trpljenja ni znanja«, »korenček znanja je grenak, čeprav so plodovi sladki«. Skeptičen odnos do znanosti izražajo tudi pregovori in rekla, ki jih je zbral Dalj: »znanost ni pivo, v usta je ne vliješ«, »dolgo živiš, dolgo se učiš, umrješ pa kot bedak«, "polizobražen je slabši od neizobraženega«, "preveč učen je slabši od neukega«, »od neznanja roke ne bolijo«, »kdor manj ve, trdneje spi«, »ni treba biti učen, treba se je znajti«. Sodobniki so star frazeologem »učeni je luč, neuki je tema« aktualizirali. Ker pa ruska mentaliteta dojema najvišji smisel preživetja v modrostih »ne izpostavljaj se« in »ne lezi preko očeta v pekel«, tj. bodi kot vsi, s tem vabi mlajše ljudi v »množico neukih«, sugerira vedenjske usmeritve, predvsem pa vztraja pri svojem razumevanju sveta. Temu sledijo tudi mladinski programi, kot so »Daj mladost!«, »Srečni skupaj« idr., še posebej pa kultni program »Dom-2«.

Medtem ko je zadovoljevanje potreb »spodnje plasti« ruske kulture pripeljalo v slepo ulico, se vztrajno pojavlja potreba po »kvalitetni televiziji«, saj lahko podobni projekti ustvarijo zgolj še različice, usmerjene k vse bolj neozaveščenemu 
gledalcu, tako da se izrabljajo stremljenje k nadaljevanju rodu, želja po užitku in samoohranitveni nagon.

Vendar je tako v zavesti gledalcev kot $\mathrm{v}$ televizijski politiki že razviden pozitivni premik. Medtem ko je študentska populacija v zadnjem desetletju kanal »Kultura« dosledno dojemala kot upokojenski, se $\mathrm{v}$ zadnjem času zainteresirano odziva na oddaje, kot so »Resnična fantastika«, »Besedni red«, »V tem času«, »Pri vas doma«, »Sfere« in celo »Biblične zgodbe«. Tudi na drugih kanalih so se pojavile kvalitetne oddaje, namenjene razmišljajočemu gledalcu različnih starostnih skupin, npr. »Tour de France«, ki jo vodita V. Pozner in I. Urgant, »Kakšen je naš čas«, ki jo vodi L. Parfenov, »Zaprto razkazovanje«, ki jo vodi A. Gordon, idr.

\section{»Družina« v nacionalni mentaliteti in na televiziij}

Za rusko mentaliteto ni mogoče reči, da ji je družina tako bistvena kot npr. za kitajsko (gl. Sun in Ščukina, 2004, 174-184), vendar zlasti v zavesti žensk ne zaseda ravno zadnjega mesta. ${ }^{4}$

Družina se v televizijskih oddajah najpogosteje pojavlja v reklamah. Televizijska reklama s svojim vplivom na gledalce oblikuje, še pogosteje pa izrablja zlasti osnovne vrednote, med katere sodi tudi koncept družine. $\mathrm{Z}$ vidika televizijske reklame načeloma ni težko slediti družbenim spremembam. »V televizijski reklami se kvaliteta življenja izboljšuje. To dokazujejo nove skupine izdelkov (kakovostna bela tehnika in avtomobili), ki jih reklamira »TV-družina«, med reklamnimi teksti pa prevladujejo »idilične« scene« (Begun, 2009, 160). Država doživlja baby boom, starši postanejo mladi, ki nimajo predstave celovite družine, in ker so jih vzgajali množični mediji (televizija in še pogosteje medmrežje), potrebujejo poduk o vodenju skupnega gospodinjstva in vzgoji otrok. Prav televizija jih je učila življenja v družini in jim dolgo oblikovala predstave o minimumu potrebnih materialnih sredstev. $\mathrm{V}$ tem času pa »se gospodinjski problemi umaknejo v ozadje, v ospredje stopi vzgoja otrok. Otroci so naposled spet pridobili status nepogrešljivega družinskega »atributa«. »Družina« je postala beseda $z$ izjemno pozitivno konotacijo, jasno izraža pomen združevanja. Vsi, ki se nahajajo v okolju družine, so dojeti kot bližnji, dragi, prežeti z vzajemno ljubeznijo«(Begun, 2009, 160).

Družine iz televizijskih nadaljevank se praviloma ne ukvarjajo posebej $\mathrm{z}$ razreševanjem otroške problematike, spominjajo na skeče, ki imajo malo skupnega

4 Frazeologemi pogosto izražajo nespoštljivo perspektivo ali celo nespoštljivo igrivost moških, ki so dojeti kot družinski vladarji, v zvezi z drugimi, podrejenimi družinskimi člani: »mladost je še zelena«, »jajce ne uči kokoši«, »mlad si, pa bi mene učil«, »dolgi lasje - kratka pamet«, »baba z voza dol, pa konj lažje vleče». 
z resničnim življenjem. Njihov glavni namen je zabavati gledalca $\mathrm{z}$ »ekscentričnimi« situacijami. Nasprotje podcenjujočemu dojemanju družine predstavljajo oddaje, kot sta »Ko so vsi doma« in »Kdo je v hiši gospodar«. Podobno kot reklame ustvarjajo vtis bleska, kar vodi v domnevo, da so namenjene še neodraslim mladim. Bližje resničnemu življenju je projekt »Osebne stvari« A. Maksimova, ki, vključno z intrigami, pogosto obravnava problematične situacije, zato je manj namenjen skupnemu družinskemu ogledu, bolj pa prispeva k oblikovanju medosebnih razmerij znotraj družine. Oddaja „Naj govorijo« A. Malahova, nasprotno, spominja na cvetnik rumenega tiska, res pa je prav v oddajah tega televizijskega voditelja mogoče zaslediti občutenje in vrednote "spodnjega sloja" ruske kulture. Televizijsko osebje ima tako možnost vplivati na mentaliteto gledalcev, s čimer želi korigirati nacionalno mentaliteto.

Očiten vzgojni značaj te socialne propagande je usmerjen k vplivu na gledalčeva čustva. Njene "trde zgodbe« so morda edina možnost za njen uspeh, saj zanesljivo najdejo občinstvo. »Ljudi smo vajeni vzgajati le do trenutka, ko so se zmožni preživljati sami in skleniti zakonsko zvezo. Potem se vzgoja konča, kot da so ljudje odtlej vsestransko usposobljeni. Odločanje o vseh večjih življenjskih problemih pa je prepuščeno individuumu in njegovi neizkušenosti. /.../ Vzgajati je mogoče tudi odraslega človeka: tudi ta je hvaležen objekt individualne vzgoje.« (Jung, 1995, 62) Vlogo takega »vzgojitelja odraslih« na srečo prevzema ruska televizija.

\section{Religiozni programi ruske televizije}

Kot že omenjeno, je najvažnejši dejavnik v formiranju nacionalne mentalitete religija, še eden v vrsti »vzgojiteljev odraslih «, ki uporablja množične medije, med drugim tudi televizijo, kot sredstvo vpliva na mentaliteto vernikov vseh veroizpovedi. Država priznava krščansko, torej pravoslavno religijo, islam, budizem in judovstvo. Razen naštetih so televizijski medij uporabljale vse krščanske veroizpovedi, npr. protestanti (predvsem baptisti), ki svoje oddaje za ozemlje Ruske federacije predvajajo iz Kazahstana. V zadnjih letih pa je s pomočjo televizije svoje poslanstvo obogatila tudi Ruska pravoslavna cerkev. »V eparhiji Jekaterinburg kot uradni medij Ruske pravoslavne cerkve deluje TV kanal 'Zveza' z oddajami, ki potekajo štiriindvajset ur dnevno v triinsedemdesetih okrožjih Ruske federacije, od tega v triinštiridesetih samo na Uralu. Kanal, upoštevaje razsežnost občinstva, zato predvaja zgolj preverjene oddaje, ki ne dopuščajo dvoma in nesporazumov.«(Ickovič, 2010, 366) Ob pravoslavnem TV kanalu delujejo še pravoslavni radio »Nedelja«, na medmrežju pravoslavne spletne strani, pravoslavni ICQ zaupanja za najstnike ter številne publikacije (časopisi, vestniki itd.).

Množični mediji različnih religij nagovarjajo različna občinstva. Do leta 2010 je Ruska pravoslavna cerkev brez odpora dopuščala spreobračanje nevernih državljanov 
Ruske federacije v druge, "tuje« krščanske veroizpovedi: Cerkev Živega Kristusa, Adventisti sedmega dne, mormoni itn. "Zaradi številnih vzrokov je v sodobni jezikovni situaciji pravoslavne cerkve postalo značilno, da se duhovnik obrača na vernike svoje cerkve, ('svoje') stalne farane, kar je vplivalo tako na vsebino kot na slog in ton besedil. 'Tujci' so pri tem pogosto ostali zunaj zornega kota dušnega pastirja. Zahvaljujoč predvsem dejavnosti patriarha Kirila Cerkev šele zadnja leta nagovarja širše občinstvo.« (Ickovič, 2010, 7)

Tradicija ruskemu človeku pripisuje emocionalno dojemanje, neprivajenost na analizo svojega ravnanja ter nagnjenost $\mathrm{k}$ občutju in ne $\mathrm{k}$ osmišljanju sveta. Tudi raziskovalci religioznega sloga in $\mathrm{v}$ zadnjem času religioznega diskurza prepoznavajo razliko med pravoslavno in drugimi krščanskimi veroizpovedmi v tem, da zahodni kristjani (katoličani, protestanti) Boga dojemajo razumsko, pravoslavni pa emocionalno. Med štirimi temeljnimi koncepti ruske mentalitete A. Vežbickaya poudarja prav emocionalnost in iracionalnost. Uvod v pravoslavno teologijo navaja:

$\mathrm{V}$ pravoslavni teologiji so poleg razumsko dojemljivih resnic tudi tiste, ki so zanj stežka ali sploh nedosegljive, tiste, ki jih torej razum ne zmore in jih nima pravice preverjati po svojih principih. (Makarij, 2000, 515)

$\mathrm{Z}$ drugimi besedami, ko študij pravoslavnih besedil sodobnemu prebivalcu Rusije zastavlja neodgovorljiva vprašanja, je potrebna zgolj vera. Gre za

vprašanja, pomembna in neizbežna za proučevanje te vere, vendar so med njimi taka, ki jih ne more razrešiti niti pravoslavna teologija, s tem pa ostaja $\mathrm{v}$ celoti zvesta svojemu izročilu, saj očitno predpostavlja, da so že bila razrešena (Makarij, 2000, 7).

Tradicija, ki v ruski mentaliteti poudarja emocionalno dojemanje, se sklicuje na Biblijo: Poslušali boste, poslušali - a ne boste doumeli, / gledali boste, gledali - a ne boste videli. / Otopelo je namreč srce temu ljudstvu; / z ušesi so težko slišali / in zatisnili so si oči, / da ne bi z očmi videli, / da ne bi z ušesi slišali; / da ne bi v srcu doumeli / [poudarila I. Š.] / in se spreobrnili / in da bi jih jaz ne ozdravil. (Mt 13, 14-15)

Pravoslavna cerkev je več kot tisoč let izrabljala način odzivanja, ki ga izraža frazeologem »jemati si k srcu«. Sodobna teorija pa emocionalno dojemanje povezuje s sposobnostjo racionalne analize, ${ }^{5}$ kar potrjujejo ruski frazeologemi »sam pomisli«, "samo pomislite«, »sedemkrat zmeri, enkrat odreži« itn. V najboljših pravoslavnih pridigah se pridigar obrača k poslušalčevemu razumu, seveda pa se pri tem bistveno opira na emocionalno sfero.

5 "... apeliranje na razum racionalni pobudi omogoča komunikacijskega partnerja prepričati v resničnost razlage, posledično pa tudi $\mathrm{v}$ to, da prevzame nase odgovornost za njeno konkretno udejanjenje (na ravni besed, misli ali delovanja)«. (Salmina, 2001, 36-37) 
N. I. Barsov ugotavlja, da didaksijo (poseben tip pridige) opredeljujejo naslednje značilnosti: (1) je vrsta - pretežno refleksivno podkrepljene - didaktike, (2) pridigo strukturno vodi razumsko razvijanje misli, (3) vsebuje presojanje in dokaze, (4) vpliva tako na čustva kot na razumsko-logični odziv. "Ko se je krščansko občestvo seznanjalo $\mathrm{z}$ novim naukom, ga je sprejemalo tako $\mathrm{z}$ emotivnim kot $\mathrm{z}$ racionalnologičnim odzivom, zanos in entuziazem prvotnih učiteljev se je zmanjševal in že pri apostolih narašča pomen didaksije.« (Barsov, 2000, T. 6, 3843) Namen pridige je poslušalca spodbuditi $\mathrm{k}$ analizi njegovih prepričanj in njihovemu udejanjanju v skladu s krščansko moralo. Prevladujoča strategija pridige je naposled vplivanje na razum, ki se konkretizira $\mathrm{z}$ uporabo logike.

\section{»Beseda pastirja« nekoč in danes v množičnih medijih}

Formalna logika predlaga tipe argumentacije, utemeljene na zakonih logike in na asociacijah. Z vidika logike je zanimiva raziskava pridig Patriarha vseya Rusi Kirila (in tudi pridig, ki jih je imel še kot metropolit), s katerimi je vrsto let nagovarjal občestvo na prvem kanalu: v njih uporablja interpretacijo, definicijo, analogijo, posplošitev, konkretizacijo itn. in tako nagovarja racionalnost svojih poslušalcev.

Tako v pridigi »O predestinaciji človeka in o nravstvenem zakonu« metropolit uporabi princip definicije, ko razpre bistvo pojma, s katerim operira: »Postati podoben pomeni spremeniti samega sebe, približati se tistemu, ki mu hočeš postati podoben.« Enako v pridigi »O dveh naravah človeka«: »Človek je bitje z dvema naravama, zgrajen iz nesmrtne duše ... in umrljivega telesa ... «V pridigi je ta definicija opredeljena kot »temeljna teza biblijske antropologije«. Pri razkrivanju dvojne narave človeškega bitja pridigar dominantno vlogo pripiše duhovnemu principu, vendar ga ne odtrga od materialnih razsežnosti. Ko pretresa možnost njune uskladitve (»harmonija« : »disharmonija«), uvede pojem pohote, ki ga opredeli na tri načine: kot

1. "konflikt med pohotami duha in mesa»

2. " $\quad$ znak notranjega razkroja, telo in duh težita v različni smeri«

3. »tisto stanje notranjega neskladja v človeškem bitju, v katerem zadovoljitev fizičnih potreb nepopravljivo škoduje duhovnim«.

$\mathrm{V}$ nadaljevanju pretresa pojem pohote duha.

Princip fizičnega uravnava duhovni princip.

Vendar je lahko duhovni princip deformiran.

Kadar kot tak škoduje človekovi fizični naravi, lahko to anomalijo opredelimo kot pohoto duha. 
Za uvedbo tega pojma je pridigar uporabil silogizem: iz dveh premis, ki sta povezani s srednjim terminom, izpelje sodbo.

V zaključku premišljevanj pridigar uporabi še posplošitev.

Tako je že ob začetku časov Bog določil namen človekovega bivanja: izpopolnitev osebe do podobnosti z Nebeškim Očetom.

V pridigi »O Jezusu Kristusu« metropolit Kristusa opredeljuje kot zgodovinsko osebnost in kot Sina Božjega, nakar svojo refleksijo posploši: „Kristus je edinstven. $\mathrm{V}$ svetovni zgodovini ni mogoče najti pojava, ki bi Mu bil podoben.« V pridigi »O namenu človeka« se sklicuje na avtoriteto, ko navaja Gregorja iz Nice: „Človeka je Stvarnik ustvaril, da bi bil živa podoba Božje in najvišje sile.« Ko razlaga navedek, pridigar uporabi interpretacijo.

»Drugače povedano, namen človeka, ki je ustvarjen po Božji podobi, je, da kot oseba postane Bogu podoben.« Pojasnjevalna strategija zagotavlja natančnost in logično razrešitev problema.

Ko razlaga moralne zakone, pridigar uporabi logično zaporedje: »razvijajoč svoje sposobnosti in notranje odlike, ... se bližamo podobi Njegove popolnosti«, »razvoj določa izpolnjevanje norm posebnega zakona«, »ta zakon pa je moralni zakon«.

Za logičnost razlage pridigar uporablja strategiji analogije in primerjave: »... ko prekršimo zakone fizičnega telesa in poškodujemo organizem, čutimo bolečino. Enako v primeru, ko prekršimo moralni zakon: boli nas in trpimo.«

Ko razlaga, kako je treba brati Biblijo, se pridigar spet zateče k analogiji:

Pridete v goste in pokažejo vam družinski album, pa slik ne morete razumeti brez komentarjev, ki vam pomagajo, da se znajdete med obrazi na slikah. Kajti družinski album pripada tej družini, zato se tujcu ni lahko znajti med temi obrazi. /.../ Biblija je knjiga Cerkve. Zato jo je treba razumeti tako, kot svoj album razume družina, ki ji ta pripada, to je kot Cerkev.

Analogija v pridigah služi predstavljanju različnih vidikov obravnavanega problema, orisu značilnih potez ter posebnim poudarkom posameznih misli, epizod in zgodovinskih dogodkov. Pridigar $\mathrm{z}$ analogijo dospe do osrednje poante svojega nastopa, do optimalne razrešitve zastavljenega problema. Analogija je v pomoč pri sistematizaciji predhodne vednosti in pripravi temeljev za predstavitev nove vednosti.

Forma, ki realizira navedene strategije logične analize, so (sestavljena) podredja. $\mathrm{V}$ religioznih besedilih delujejo podobno kot podobne konstrukcije $\mathrm{v}$ znanstvenih besedilih, kar potrjuje hipotezo o racionalnem nagovoru religioznih besedil. $\mathrm{V}$ 
posameznih primerih pa uporaba podredij ustreza funkciji publicističnih besedil - tu gre za racionalizacijo emotivnega vpliva (gl. Ščukina in Hazanži, 2010, 224).

Poseben pomen $\mathrm{v}$ dialogu patriarha in metropolita Kirila $\mathrm{z}$ gledalcem ima tonaliteta. Do leta 2009 jo je mogoče opredeliti kot ganljivo, iskreno, prijazno poučevalno; pridigar se istoveti $\mathrm{z}$ gledalcem in govori v prvi osebi množine: »... ko prekršimo zakone fizičnega telesa in poškodujemo organizem, čutimo bolečino. Enako v primeru, ko prekršimo moralni zakon: boli nas in trpimo.« (poudarila I. Š.) Temu služi tudi analogija $\mathrm{z}$ družinskim albumom, $\mathrm{z}$ družino. Ta je, kot rečeno, ena od temeljnih vrednot ruske mentalitete. Metropolit Kiril tako izraža sočutje z verniki ter pripravljenost na pomoč pri težavah in razreševanju težavnih primerov znotraj Ruske pravoslavne cerkve, prav kakor se pričakuje od »glavarja družine«, očeta, pastirja, saj so pravoslavni gledalci dojeti kot bratje in sestre $\mathrm{v}$ Kristusu. V posameznih besedilnih primerih govorec uporablja strukturo prepričevanja, značilno za vzgojitelja nevednega otroka: »človek je bitje z dvema naravama, zgrajen iz nesmrtne duše ... in umrljivega telesa ...«, »in Bog človeku pomaga na tej poti, blagoslavlja ga, mu daje moč, obdaruje ga z življenjem v Bogu.« Drugje besedilo uporabi strategijo pojasnjevanja, ki omogoča logično predstavitev in hkrati mehča zapletenost zastavljenega problema:

Po obeh koledarjih se Božič praznuje 25. decembra, med obema pa je razlika trinajstih dni, zato 25. december po julijanskem koledarju (po starem štetju) ustreza 7. januarju po gregorijanskem (po novem).

Tonaliteta ne izhaja le iz izbranega besedišča, ki naj izraža govorčevo iskrenost do poslušalca, marveč tudi iz izbire intonacijskih konstrukcij: praviloma gre za konstrukcije s padajočo intonacijo. Kot priporoča homiletika, metropolit Kiril uporablja povišane tone v osrednjem delu sintagme (gl. Brizgunova, 1981; Ovčinikova, Ponomarev, Ščukina, 2007, 87-93), prehod na višjo barvo glasu pa govor napravi izrazitejši in zaupljivejši.

Iskrenost je najvišja vrednota v ruski mentaliteti. Od tod uporaba televizijskega zaslona, ki načeloma ne omogoča laganja. "Za rusko kulturo komunikacije sta značilni iskrenost in odkritost: kolektivna bit ruskega človeka predpostavlja, da vsi vedo vse drug o drugem, prikrivanja pred okolico ne sme biti. Od tod navada in težnja, da se čustev in razpoloženj ne skriva." (Prohorov in Sternin, 2007, 154) V ruski mentaliteti je vsak, ki skriva svoje misli, dojet kot sumljiv in si ne zasluži zaupanja. Tonaliteta, ki najbolj spodbuja zaupanje, je uporabljena $\mathrm{v}$ nastopih metropolita Kirila zlasti tedaj, ko nagovarjanje gledalčevega razuma ni možno, torej ko gre za govor o čudežih: tudi »na temelju vsega znanja, s katerim razpolaga človeštvo, čudež ne more biti razumsko in prepričljivo razložljiv«.

Tonaliteta nastopov patriarha Kirila se bistveno razlikuje od tonalitete v oddajah metropolita Kirila. Nenazadnje oddaja »Beseda pastirja«, ki sicer ostaja na prvem 
kanalu televizije, posreduje samo še javne nastope višjih avtoritet Ruske pravoslavne cerkve. Število višjih tonov v glasu vladike se zniža, glas je torej nižji, v njem so prvine pretrganosti, zveni »kovinsko«. Osebnega poglobljenega pogovora z verniki - in tudi patriarhovega časa zanj - ni več, saj javni govor ne dopušča takega (po)govora.

Patriarh kot poprej uporablja podredja in nagovarja poslušalčev razum:

Da bi ljubili vse, je treba ljubiti svojega očeta in mater, svojo ženo in otroke. Če postane najvišji blagor ljubezen, bo človek, ki je ni deležen, hrepenel po nji.

Vendar uporaba teh konstrukcij pridobi drugačno konotacijo. V javno govorjenih pridigah je za tak žanr primerna intonacijska konstrukcija $\mathrm{z}$ rastočo intonacijo, ki mora vplivati predvsem na poslušalčevo nezavedno ter vzpostaviti množično občinstvo kot člane kakega občestva. Posledica je izguba »intimnosti« v razmerju med govorcem in poslušalci, v nagovoru občinstva se pojavlja odtenek uradnosti. Vendar pa

Rusi niso pripravljeni poslušati uradnih poročevalcev. /.../ To je povezano s predstavo o uradnem ukrepu kot ritualu, ki se ga je treba sicer udeležiti, "ga odkljukati«. Ruski človek ne mara uradnih, formalnih stikov in je mnenja, da take situacije zahtevajo prisotnost, ne pa pozornost. (Prohorov in Sternin, 2007, 198)

Kolektivno gledanje televizije danes ni več v navadi. Gledalec gleda priljubljenega voditelja v svoji zasebnosti, ni se mu treba odzvati. Po drugi strani pa vloga zgolj "opazovalca « ne ugaja vsem, saj niso po naključju postale popularne oddaje, v katerih je gledalec postavljen tako rekoč v vlogo sodelavca, ko dobi pravico glasovanja o kakem problemskem vprašanju. Sodobni gledalec se obrača k televiziji v želji po individualni, skoraj intimni pozornosti, ki jo nerad išče pri uradni osebi. Tudi zato se je močno skrajšal spisek vprašanj, ki so jih v preteklem letu poslušalci naslavljali na vladiko, saj se je patriarh nehal pojavljati kot individuum. Pravoslavno občinstvo naj bi težko pričakovalo čas, ko bo delo vodje vseh vladiki dopustilo, da se vrne k vsaki svoji ovčici.

\section{Zaključek}

Analiza sprememb na ruski televiziji je pokazala, da se te dogajajo počasi, a zanesljivo:

- $\quad$ pojavili so se kvalitetni programi;

- $\quad$ povečalo se je število izobraževalnih oddaj in kanalov;

- izraba nacionalnih mentalitetnih vrednot je privedla k težnji po vplivu na njihovo formiranje; koncept »družine« tako vrsta vodilnih televizijskih programov razume kot najvišjo in nesporno vrednoto;

- Ruska pravoslavna cerkev je aktivirala svojo vzgojno dejavnost, tako da je s prisotnostjo na televiziji postala konkurenčna drugim krščanskim veroizpovedim. 
$S$ to politiko ruski množični mediji znova pridobivajo status institucije, ki nima zgolj možnosti formiranja družbene zavesti, marveč jo tudi dejansko formira. Pri tem ne gre za ideološko obdelavo, marveč za ozaveščanje državljanov za pogled na svet, ki pri različnih interpretacijah temeljnih vrednot državljanu pripomore $\mathrm{k}$ sprejetju stališča, da absolutna resnica ne obstaja, temveč je intelektualni napor, ki vključuje izbiro lastne poti, potreba, ki se spoštuje in do katere ima pravico vsak. 


\section{Literatura}

Annenkova, 2009 / Анненкова И.В. Риторика гедонизма в современных СМИ// Досуговая журналистика в России. Материалы Межвузовской научнопрактической конференции 27-28 мая 2009г., г. Санкт-Петербург. СПб, 2009.

Annenkova, 2010a / Анненкова И.В. Широкий путь гедонизма в современных СМИ// Медиа. Демократия. Рынок. Часть 2. Функционирование средств массовой информации в сфере досуга. Материалы Международной научнопрактической конференции 24-25 мая 2010г. СПб, 2010.

Annenkova, 2010b / Анненкова И.В. Риторика как универсальная основа описания медиадискурса// Доклады Международной научной конференции «Стилистика сегодня и завтра: медиатекст в стилистическом, риторическом и лингвокультурологическом аспектах». М., 2010.

Barsov, 2000 / Барсов Н.И. Проповедь. Словарь Брокгауза и Эфрона, 2000, Т. 6: 3843.

Begun, 2009 / Бегун В.В. Современная семья в телевизионной рекламе// Медиа, демократия, рынок в современном обществе. Материалы 111 Межвузовской научно-практической конференции 19-20 мая 2009г. СПб, 2009.

Bryzgunova, 1981 / Брызгунова Е.А. Звуки и интонация русской речи. М., 1981.

Gumilev, 2002 / Гумилев Л.Н. Этногенез и биосфера земли. СПб, 2002.

Ickovič, 2010 / Ицкович Т.В. Современные православные СМИ: функциональностилевая принадлежность/Речеведение: современное состояние и перспективы. Материалы Международной научной конференции, посвященной юбилею М.Н.Кожиной (Пермь, 16-20 ноября 2010г.). Пермь, 2010.

Jung, 1995 / Юнг К.Г. Конфликты детской души. М., 1995.

Makarij, 2000 / Макарий Д.Б. преп. Введение в православное Богословие. Минск Москва, 2000.

Mečkovskaya, 2000 / Мечковская Н.Б. Социальная лингвистика. М., 2000.

Ovčinikova, Ponomarev, Ščukina, 2007 / Овчинникова И.Г., Пономарев Н.Ф., Щукина И.Н. Речевая коммуникация в ситуации билингвизма. Пермь, 2007.

Prohorov in Sternin, 2007 / Прохоров Ю.Е., Стернин И.А. Русские: коммуникативное поведение. М., 2007.

Rezvuškina, 2002 / Резвушкина Т. Использование метода семантического дифференциала при изучении гендерных стереотипов//Гендерные исследования в Центральной Азии. Алматы: Центр гендерных исследований, 2002. 
Rudnev, 1997 / Руднев В.П. Словарь культуры ХХ века. М., 1997.

Salmina, 2001 / Салмина Л.М. Коммуникация. Язык. Мышление. Казань, 2001.

Solganik, 2002 / Солганик Г.Я., Дроняева Т.С. Стилистика современного русского языка и культура речи. М., 2002.

Sun in Ščukina, 2004 / Сунь С., Щукина И.Н. Фрагменты языковой картины мира через призму фразеологизмов// Филологические заметки. Вып.3. Пермь, 2004.

Ščukina, 2010 / Щукина И.Н. Языковая картина мира: на пути к гармонии. Очерки по межкультурной коммуникации. Пермь, 2010.

Ščukina in Hazanži, 2010 / Щукина И.Н., Хазанжи Е.И. Функционирование сложноподчиненных предложений в телевизионных проповедях (на материале проповедей митрополита Смоленского и Калининградского Кирилла)// Медиа. Демократия. Рынок. Часть 2. Функционирование средств массовой информации в сфере досуга. Материалы Международной научнопрактической конференцмм 24-25 мая 2010г. СПб., 2010: 224.

Trubeckoj, 2007 / Трубецкой Н.С. Наследие Чингисхана. М., 2007.

Vereščagin in Kostomarov, 2005 / Верещагин Е.M., Костомаров В.Г. Язык и культура. 2005.

Патриарх Всея Руси Кирилл «Слово Пастыря» от 9 января. 
Irina N. Ščukina

\section{Russian TV in 2010 and the Image of the World}

Keywords: mass media, national mentality, Orthodox sermons, Patriarch Cyril, audience

This article addresses how the image of the world is presented in the Russian media. In particular, it examines the religious sermons of Patriarch Cyril in his TV broadcasts and analyses how the national image of the world is reflected in them. 